\title{
PERSEPSI PERAWAT TENTANG JENJANG KARIR DI RSUD TUGUREJO SEMARANG
}

\author{
Mona Saparwati, ${ }^{1}$ ) Mutinik ${ }^{2}$ ) \\ 1. Staff Pengajar Program Studi S1 Keperawatan Universitas Ngudi Waluyo \\ 2. Perawat RSUD Tugurejo Semarang \\ Email: mona_saparwati@ymail.com
}

\begin{abstract}
ABSTRAK
Pengembangan karir perawat merupakan suatu perencanaan dan penerapan rencana karir yang dapat digunakan untuk penempatan perawat pada jenjang yang sesuai dengan keahliannya. Departemen kesehatan Republik Indonesia bersama PPNI telah mengeluarkan pedoman jenjang karir perawat. RSUD Tugurejo menerapkan sistem jenjang karir mulai tahun 2014. Perawat mempersepsikan bahwa jenjang karir adalah level dari pekerjaan.Tujuan penelitian ini adalah mengetahui gambaran persepsi perawat tentang jenjang karir di RSUD Tugurejo Semarang. Desain penelitian ini adalah deskriptif dengan pendekatan cross sectional. Sampel dalam penelitian ini 79 responden. Pengambilan data menggunakan kuesioner. Analisa data mengunakan distribusi frekuensi. Hasil penelitian menunjukkan bahwa persepsi perawat tentang jenjang karir di RSUD Tugurejo Semarang baik dengan hasil $75 \%$ baik. Hasil penelitian dari tingkatan jenjang karir perawat sebagian besar baik sebanyak 48 responden $(60,8 \%)$, manfaat jenjang karir perawat sebagian besar baik sebanyak 55 responden $(69,6 \%)$, standar kompetensi jenjang karir perawat sebagian besar baik sebanyak 40 responden $(50,6 \%)$, mekanisme kenaikan jenjang perawat sebagian besar kurang baik sebanyak 46 responden $(41,8 \%)$. Berdasarkan hasil penelitian yang dilakukan maka saran kepada rumah sakit untuk memberikan dorongan kepada perawat untuk semangat dalam mengikuti mekanisme kenaikan jenjang karir.
\end{abstract}

Kata kunci : Jenjang Karir, Persepsi, Perawat

\begin{abstract}
Nursing career development is a planning and implementation of a career plan that can be used for the placement of nurses in accordance with the level of expertise. Department of Health of Republic of Indonesia together with PPNI have issued the guidelines for nursing careers. RS Tugurejo has implemented a career level system began in 2014. The purpose of this study was to determine the description of nurses perception about career level at RSUD Tugurejo Semarang. This study used descriptive approach with cross sectional design of the 79 respondents using a questionnaire. The results show the nurse's perception about the nurse's perception about the career level of nurses is mostly good by $75 \%$, the level of career mostly good by 48 respondents $(60,8 \%)$, the perception of nurses about the benefits of nurse career is mostly good by 55 respondents (69.6\%), the nurse's perception about competency standards of nurse career is mostly good by 40 respondents $(50,6 \%)$, the nurse's perception about the mechanism of nurse career development is mostly poor as many as 46 respondents $(58.2 \%)$. Based on the results of this research, the advice to hospital is to improve the implementation within the nurses competency and encourage the nurses to follow the mechanism of the development in career level.
\end{abstract}

Keywords $\quad$ : career level, nurse,Perception 


\section{PENDAHULUAN}

Perawat sebagai salah satu tenaga kesehatan di rumah sakit memegang peranan penting dalam upaya mencapai tujuan pembangunan kesehatan. Keberhasilan pelayanan kesehatan bergantung pada partisipasi perawat dalam memberikan perawatan yang berkualitas bagi pasien (Potter \& Perry, 2005). Hal ini terkait dengan keberadaan perawat yang bertugas selama 24 jam melayani pasien serta jumlah perawat yang mendominasi tenaga kesehatan di rumah sakit, yaitu berkisar 40-60\% (Swansburg, 2000).

Pengembangan karir perawat merupakan suatu perencanaan dan penerapan rencana karir yang dapat digunakan untuk penempatan perawat pada jenjang yang sesuai dengan keahliannya, serta menyediakan kesempatan yang lebih baik sesuai dengan kemampuan dan potensi perawat (Marquis \& Huston, 2010). Sistem yang dikembangkan mengacu pada aturan yang diperuntukan bagi pegawai negeri sipil (PNS), berdasarkan SK Menpan No. 94/KEP/ M.PAN/11/2001 tentang jabatan fungsional perawat termasuk angka kreditnya (Depkes, 2006).

Secara umum manfaat penerapan sistem jenjang karir menurut Sulistiyani dan Rosidah (2003) adalah mengembangkan prestasi pegawai, mencegah pegawai minta berhenti karena pindah kerja, meningkatkan loyalitas pegawai, memotivasi pegawai agar dapat mengembangkan bakat dan kemampuannya, mengurangi subjektivitas dalam promosi, memberi kepastian hari depan, mendukung organisasi memperoleh tenaga yang cakap dan terampil melaksanakan tugas.

Sejalan dengan itu pula, secara praktik beberapa rumah sakit di Indonesia telah menetapkan sistem jenjang karir berdasar kompetensi sesuai kebutuhan masingmasing, misalnya Rumah Sakit (RS) Imanuel Bandung, RS PGI Cikini Jakarta dan RS Jantung Harapan Kita Jakarta. Sistem jenjang karir yang telah dilaksanakan di RS Imanuel Bandung menggunakan penjenjangan perawat klinik (PK) mulai dari PK 1, 2, 3, 4 dan 5; perawat manajer (PM) mulai dari PM 1, 2, 3 dan PM 4; perawat pendidik (PP) mulai dari PP 1, 2 dan PP 3; serta perawat riset 
(PR) yang terdiri dari PR 1 dan 2. Evaluasi terhadap sistem ini dapat disimpulkan bahwa mutu pelayanan meningkat, khususnya pelayanan keperawatan (Susana, 2007).

Survey pada suatu Rumah Sakit Umum Daerah di Jawa Tengah oleh mahasiswa residensi dari Fakultas Ilmu Keperawatan (FIK) UI tahun 2009 menjelaskan bahwa 58,33\% kepala ruangan menyatakan perlu adanya pengembangan karir bagi perawat, sedangkan $52 \%$ perawat pelaksana menyatakan belum memahami tentang sistem jenjang karir, sehingga pada saat itu disepakati adanya masalah; kurang optimalnya pola pengembangan karir keperawatan di rumah sakit tersebut (Linggardini, 2009). Data hasil survey tahun 2010 di rumah sakit yang sama menyatakan bahwa $88,6 \%$ kepala ruang dan $94,3 \%$ ketua tim/perawat pelaksana menyatakan perlu adanya jenjang karir perawat klinik. (Suroso, 2010).

Tujuan Penelitian dari penelitian ini adalah mengetahui gambaran persepsi perawat tentang jenjang karir dalam di RSUD Tugurejo Semarang. Jenis penelitian yang digunakan adalah penelitian deskriptif. Penelitian deskriptif bertujuan untuk mendeskripsikan atau memaparkan peristiwa-peristiwa penting yang terjadi pada masa kini (Nursalam, 2010). Populasi dalam penelitian ini adalah perawat RSUD Tugurejo Semarang. Sampel dalam penelitian ini adalah 79 responden dengan simple random sampling.

\section{Tinjauan Teoritis}

Persepsi adalah proses yang digunakan individu mengelola dan menafsirkan kesan indera mereka dalam rangka memberikan makna kepada lingkungan mereka. Meski demikian apa yang dipersepsikan seseorang dapat berbeda dari kenyataan yang obyektif (Robbins, 2006). Persepsi adalah proses pengorganisasian, penginterpretasian, terhadap rangsang yang diterima oleh organisme atau individu sehingga merupakan sesuatu yang berarti dan merupakan aktivitas yang integrated dalam diri individu (Sunaryo, 2004). 
Persepsi merupakan hasil kerja otak dalam memahami atau menilai sesuatu hal yang terjadi di sekitarnya. Persepsi adalah hasil pikir sementara terhadap stimulus diluar diri kita (Waidi, 2006). Berdasarkan beberapa pengertian diatas maka dapat disimpulkan persepsi adalah proses yang digunakan individu mengelola dan menafsirkan kesan indera mereka dalam rangka memberikan makna kepada lingkungan mereka sehingga merupakan sesuatu yang berarti dan merupakan aktivitas yang integrated dalam diri individu.

Karir Perawat menurut Depkes (2006) merupakan sistem untuk meningkatan kinerja dan profesionalisme sesuai dengan bidang pekerjaan melalui peningkatan kompetensi. Sistem jenjang karir profesional memuat tiga aspek yang saling berhubungan, yaitu kinerja, orientasi profesional dan kepribadian perawat, serta kompetensi yang menghasilkan kinerja profesional (Depkes, 2006).

Komponen utama karir meliputi alur karir, tujuan karir, perencanaan karir dan pengembangan karir. Alur karir adalah pola pekerjaan yang berurutan yang membentuk karir seseorang. Tujuan karir merupakan pernyataan tentang posisi masa depan dimana seseorang berupaya mencapainya sebagai bagian dari karir hidupnya. Tujuan karir menunjukkan kedudukan seseorang sepanjang karir pekerjaannya. Perencanaan karir merupakan proses dimana seseorang menyeleksi tujuan karir dan arus karir untuk mencapai tujuan tersebut, sedangkan pengembangan karir seseorang meliputi perbaikan-perbaikan personal yang dilakukan untuk mencapai rencana dan tujuan karirnya.

Pencapaian tujuan dan rencana karir seseorang tidak hanya ditentukan oleh sistem karir yang ditetapkan di tempat kerja tersebut. Perawat sebagai individu yang merupakan SDM yang bekerja pada suatu organisasi pelayanan kesehatan/rumah sakit, mempunyai peran yang sangat besar dalam pencapaian karir perawat itu sendiri. Lima faktor yang terkait dengan karir meliputi; keadilan dalam karir, perhatian dengan penyeliaan, kesadaran tentang kesempatan, minat pekerja dan kepuasan karir.njangan karir 


\section{Metode Penelitian}

Jenis penelitian yang digunakan adalah penelitian deskriptif. Penelitian deskriptif bertujuan untuk mendeskripsikan atau memaparkan peristiwa-peristiwa penting yang terjadi pada masa kini (Nursalam, 2010). Penelitian dilakukan di RSUD Tugurejo Semarang. Populasi dalam penelitian ini adalah semua perawat yang ada di RSUD Tugurejo Semarang sebanyak 383 perawat. Besar sampel dalam penelitian ini adalah dibulatkan menjadi 79 responden. Instrumen yang digunakan dalam penelitian ini yaitu menggunakan kuesioner

\section{Hasil Penelitian}

1. Gambaran Persepsi Perawat tentang Jenjang Karir di RSUD Tugurejo

Tabel 4.7 Gambaran persepsi perawat tentang jenjang karir di RSUD Tugurejo Semarang

\begin{tabular}{lll}
\hline \multicolumn{1}{c}{ Kategori } & Frekuensi & Persentase (\%) \\
\hline Baik & 3 & 75 \\
Kurang Baik & 1 & 25 \\
\hline Jumlah & $\mathbf{4}$ & $\mathbf{1 0 0}$ \\
\hline
\end{tabular}

2. Gambaran persepsi perawat tentang tingkatan jenjang karir perawat di RSUD Tugurejo Semarang

Tabel 4.8 Gambaran persepsi perawat tentang tingkatan jenjang karir perawat di RSUD Tugurejo Semarang

\begin{tabular}{lll}
\hline \multicolumn{1}{c}{ Kategori } & Frekuensi & Persentase (\%) \\
\hline Baik & 48 & 60,8 \\
Kurang Baik & 31 & 39,2 \\
\hline Jumlah & $\mathbf{7 9}$ & $\mathbf{1 0 0}$ \\
\hline
\end{tabular}

3. Gambaran persepsi perawat tentang manfaat jenjang karir perawat di RSUD Tugurejo Semarang

Tabel 4.9 Gambaran persepsi perawat tentang manfaat jenjang karir perawat di RSUD Tugurejo Semarang

\begin{tabular}{lll}
\hline Kategori & Frekuensi & Persentase (\%) \\
\hline Baik & 55 & 69,6 \\
Kurang Baik & 24 & 30,4 \\
\hline Jumlah & $\mathbf{7 9}$ & $\mathbf{1 0 0}$ \\
\hline
\end{tabular}




\section{Pembahasan}

Berdasarkan hasil perhitungan pada tabel 4.7 menunjukkan bahwa sebagian besar perawat memiliki persepsi yang baik tentang jenjang karir di RSUD Tugurejo yaitu sebanyak 3 sub variabel dengan hasil baik. Tingkatan yang baik terdiri dari Tingkatan, Manfaat dan Standar kompetensi dan sedikit kurang baik di sektor mekanisme jenjang karir. Perbandingan antara jumlah perawat yang mempersepsikan baik dan kurang baik tidak begitu signifikan jaraknya dengan jarak terbesar adalah berselisih $17 \%$.

Menurut Chaplin (2008), persepsi secara umum bergantung pada faktor-faktor perangsang, cara belajar, keadaan jiwa atau suasana hati, dan faktor-faktor motivasional. Robbins (2010) mengemukakan bahwa adanya perbedaan karakteristik dalam diri individu akan menimbulkan perbedaan pula di dalam mempersepsikan pengembangan karir. Selain itu perawat yang mempersepsi pengembangan karirnya secara positif cenderung mempunyai sikap kerja yang baik dan kepuasan kerja yang tinggi, sehingga akan menghindari berbagai sikap dan perilaku kerja yang menghambat pencapaian tujuan organisasi. Dua proses yang perlu dijaga persepsi yang bagus dalam jenjang karir di RSUD tugurejo adalah bagaimana perawat merencanakan dan mengimplementasikan tujuan karir perawat sendiri (perencanaan karir) dan bagaimana rumah sakit mendesain dan mengimplementasikan program pengembangan karir perawat (manajemen karir).

\section{Gambaran persepsi perawat tentang tingkatan jenjang karir perawat di RSUD Tugurejo Semarang}

Berdasarkan hasil perhitungan pada tabel 4.8 menunjukkan bahwa sebagian besar perawat memiliki persepsi yang baik tentang tingkatan jenjang karir perawat yaitu sebanyak 48 responden (69,6\%). Menurut Depkes RI (2006) bahwa sistem jenjang karir ditentukan dengan tingkat pendidikan dan masa kerja. Perawat Klinik I (Novice) adalah perawat lulusan D-III telah memiliki pengalaman kerja 2 tahun atau Ners. Perawat Klinik II (Advance Beginner) adalah perawat lulusan D -III. Keperawatan dengan pengalaman kerja 5 tahun 
atau Ners (lulusan S-1 Keperawatan plus pendidikan profesi) dengan pengalaman kerja 3 tahun, dan mempunyai sertifikat PK-II. Perawat Klinik III (competent) adalah perawat lulusan D-III Keperawatan dengan pengalaman kerja 9 tahun atau Ners Perawat Klinik IV (Proficient) adalah Ners (lulusan S-1 Keperawatan plus pendidik padaan profesi) dengan pengalaman kerja 9 tahun atau Ners Spesialis dengan pengalaman kerja 2 tahun, dan memiliki sertifikat PK memiliki sertifikat PK-IV, atau Ners Spesialis Konsultan dengan pengalaman kerja 0 tahun. Perawat Klinik V (Expert) adalah Ners spesialis dengan pengalaman kerja 4 tahun atau Ners Spesialis Konsultan dengan pengalaman kerja 1 tahun, dan memiliki sertifikat PK-V.

\section{Gambaran persepsi perawat tentang manfaat jenjang karir perawat di RSUD Tugurejo Semarang}

Berdasarkan hasil perhitungan pada tabel 4.9 menunjukkan bahwa sebagian besar perawat memiliki persepsi yang baik tentang manfaat jenjang karir perawat yaitu sebanyak 55 responden $(69,6 \%)$. Manfaat jenjang karir menurut persepsi perawat dapat meningkatkan kinerja perawat pelaksana, dan menurut Marquis \& Huston (2010) pengembangan karir adalah perencanaan dan implementasi rencana karir dan dapat dipandang sebagai proses hidup kritis yang melibatkan individu dan pegawai. Penciptaan tangga karir dan program melanjutkan pendidikan oleh organiasi juga dapat mengarah pada pemberdayaan perawat (Laschinger \& Havens, 1996 dalam Marquis \& Huston, 2010). Sistem jenjang karir juga bermanfaat untuk memperbaiki moral perawat melalui kepuasan kerja akibat pekerjaan yang dilakukan.

Hasil penelitian yang pernah dilakukan oleh Suroso (2011) di RSUD Banyumas menunjukkan bahwa persepsi tentang jenjang karir yang meliputi pengembangan karir, penghargaan, pengakuan berhubungan dengan kepuasan kerja dan kinerja perawat. Sejalan dengan hasil penelitian Trialfian (2011) yang dilakukan di rumah sakit se-Karesidenan Surakarta bahwa semakin 
tinggi adanya kesempatan pengembangan karir, maka semakin tinggi pula kinerja karyawan.

\section{Gambaran persepsi perawat tentang standar kompetensi jenjang karir perawat di RSUD Tugurejo Semarang}

Berdasarkan hasil perhitungan pada tabel 4.10 menunjukkan bahwa sebagian besar perawat memiliki persepsi yang baik tentang standar kompetensi jenjang karir perawat yaitu sebanyak 40 responden $(50,6 \%)$. Penetapan kompetensi perawat Indonesia mengacu pada ketentuan Standar Kompetensi Perawat Indonesia dari PPNI dan Direktorat Keperawatan dan Keteknisan Medis. Kompetensi jenjang terbagi dalam lima macam kompetensi yaitu kompetensi Keperawatan Dasar Umum, kompetensi Keperawatan Lanjutan atau kompetensi Keperawatan Dasar Spesialistik, kompetensi Keperawatan Spesialistik Umum, kompetensi Keperawatan Spesialistik Khusus, dan kompetensi Keperawatan Konsultan Spesialistik.

\section{Gambaran persepsi perawat tentang mekanisme kenaikan jenjang karir} perawat di RSUD Tugurejo Semarang

Berdasarkan hasil perhitungan pada tabel 4.11 menunjukkan bahwa sebagian besar perawat memiliki persepsi yang kurang baik tentang mekanisme kenaikan jenjang karir perawat yaitu sebanyak 46 responden $(58,2 \%)$. Hal ini menunjukkan bahwa perawat masih belum memahami tentang mekanisme kenaikan jenjang karir perawat. Mekanisme kenaikan jenjang karir perawat menurut Depkes RI (2006) adalah uji kompetensi jenjang karir SDM Keperawatan dilakukan pada saat rekrutmen dan pengembangan SDM Keperawatan yang sedang bekerja di Rumah Sakit. Pada tahap awal uji kompetensi difokuskeman untuk perawat klinik. Proses pelaksanaannya dibagi dalam empat tahap, yaitu tahap pendaftaran, tahap Proses Pemenuhan Kompetensi, ujian kompetensi dan Penetapan Jenjang Karir yang Baru. 


\section{Kesimpulan}

Persepsi perawat tentang tingkatan jenjang karir perawat sebagian besar baik sebanyak 48 responden $(60,8 \%)$. Persepsi perawat tentang manfaat jenjang karir perawat sebagian besar baik sebanyak 55 responden $(69,6 \%)$. Persepsi perawat tentang standar kompetensi jenjang karir perawat sebagian besar baik sebanyak 40 responden $(50,6 \%)$. Persepsi perawat tentang standar kompetensi kenaikan jenjang perawat sebagian besar kurang baik sebanyak 46 responden $(58,2 \%)$.

\section{Saran}

Hasil penelitan ini dapat menjadi masukan bagi Rumah Sakit untuk dapat memberikan motivasi kepada para perawat akan bersemangat dalam mengikuti proses mekanisme kenaikan jenjang karir misalnya memberikan reward yang berbeda kepada perawat klinik dimana semakin tinggi level jenjang karir maka akan mendapat reward yang lebih tinggi.

\section{Daftar pustaka}

Arikunto, S. (2010). ProsedurPenelitian Suatu Pendekatan Praktek. Jakarta : Rineka Cipta.

Depkes RI. (2006). Keputusan Menteri Kesehatan RI nomor : 836/MENKES/SK/VI/2005 tentang Pedoman pengembangan manajemen kinerja perawat dan bidan. Jakarta : Depkes RI

Depkes RI (2004).Rancangan pedoman pengembangan sistem jenjang karir profesional perawat,. Jakarta: Direktorat Keperawatan dan keteknisian Medik Dirjen Yan Med Depkes RI.

Gustini. (2007). Jenjang Karir. Available at : http://pkko.fik.ui.ac.id/ diakses tanggal 10 November 2015.

Hidayat, A.A. (2010). Metode Penelitian Kebidanan \& Teknik Analisis Data. Jakarta : Salemba Medika

Marquis, B.L. \& Huston, C., J. ( 2010). Kepemimpinan dan manajemen keperawatan: teori \& aplikasi, ed 4, alih Bahasa, Widyawati dkk, Editor edisi bahasa IndonesiaEgi komara yuda dkk, Jakarta: EGC

Notoatmodjo, S. (2012). Metodologi penelitian kesehatan. Jakarta : Rineka cipta 
Nurhidayah. (2005). Sistem Pengembangan Karir Perawat. Jurnal Keperawatan Rufaidah Sumatra Utara, Vol.1, 24-30. Medan: Program Studi Ilmu Keperawatan Universitas Sumatra Utara.

Nursalam. (2010). Konsep dan Penerapan Metodologi Penelitian Ilmu Keperawatan. Jakarta : Salemba Medika.

Nursalam dan Efendi. (2008). Pendidikan Dalam Keperawatan. Jakarta : Salemba Medika.

Potter \& Perry. (2010). Buku Ajar Fundamental Keperawatan: Konsep, Proses, dan Praktik. Alih bahasa: Yasmin Asih. Edisi 4. Jakarta : EGC.

Robbins. (2006). Perilaku Organisasi. Jakarta : Indeks.

Saragih. (2013). Hubungan jenjang Karir dengan Kepuasan Kerja Perawat di RS Santo Barromeus Bandung. STIkes Santo Borromeus, Jul i 2013.

Saryono. (2009). Metodologi Penelitian Kesehatan. Yogyakarta ; Nuhan Medika

Sirait. (2010). Memahami Aspek-Aspek Pengelolaan Sumber Daya Manusia dalam Organisasi. Jakarta : Grasindo.

Sulistiyani, A.T. \& Rosidah (2003). Manajemen sumber daya manusia: konsep, teori dan pengembangan dalam konteks organisasi publik. Yogyakarta: Graha Ilmu.

Sunaryo. (2004). Psikologi Untuk Keperawatan. Jakarta: EGC.

Suroso. (2011). Hubungan Persepsi tentang Jenjang Karir dengan Kepuasan Kerja dan Kinerja Perawat RSUD Banyumas. Tesis. Jakarta : UI.

Suroso. (2011). Penetapan Sistem Jenjang Karir Berdasarkan Kompetensi Untuk Meningkatkan Kepuasan Kerja dan Kinerja Perawat di Rumah Sakit. Ekplanasi Volume 6 Nomor 2 Edisi September 2011.

Susana. (2007). Pola Pelatihan Perawat Fungsional di RS Immanuel Bandung. Materi Semiloka di RSKD Jakarta.

Waidi. (2006). The Art Of Re-Engineering Your Mand For Success. Jakarta : Elex Media Komputindo.

Widayatun. (2005). Ilmu Perilaku. Jakarta : Rineka Cipta 